\title{
Gas-Phase Ion-Molecule Chemistry of Borate and Boronate Esters
}

\author{
Jeffrey P. Kiplinger* \\ Department of Chemistry, Indiana University, Bloomington, Indiana, USA
}

\author{
Catherine A. Crowder, ${ }^{\dagger}$ Daniel N. Sorensen, ${ }^{\ddagger}$ and John E. Bartmess \\ Department of Chemistry, University of Tennessee, Knoxville, Tennessee, USA
}

Borate esters $\mathrm{B}(\mathrm{OR})_{3}$ and boronate esters $\mathrm{RB}(\mathrm{OR})_{2}$ undergo ion-molecule reactions to yield both addition products (by an implied radiative emission mechanism), ligand exchange, and proton transfer products, in both positive and negative ion modes. Although an acidity for $\mathrm{CH}_{3} \mathrm{~B}(\mathrm{OR})_{2}$ could not be determined, $\mathrm{HOB}(\mathrm{OR})_{2}$ has an acidity between acetaldehyde and nitromethane. In light of the negligible polar electron acceptor properties of the $-B(O R)_{2}$ group, that functionality must therefore be one of the best resonance electron acceptor groups known, almost half again as effective as the nitro group. ( $\mathrm{Am}$ Soc Mass Spectrom 1994, 5, 169-176)

$\mathrm{T}$ The ability of boron to act as a Lewis acid via its empty p orbital is well known [1]. The ability of this empty orbital to act as a stabilizing functionality for Brønsted acids, by charge delocalization from an adjacent anion, as shown in 1, has not been as extensively explored. The isoelectronic relationship that the boron atom has to electron-deficient carbon (i.e., $\mathrm{R} 3 \mathrm{~B}$ and $\mathrm{R} 3 \mathrm{C}^{+}, \mathrm{RB}(\mathrm{OH}) 2$, and $\mathrm{RCO} 2 \mathrm{H}$, etc.) provides a useful rationale for this ability. Behavior of this latter type has not been widely investigated in solution, because solvents polar enough to solvate such anionic species are in general also good Lewis bases and will complex with the boron, thus destroying the possibility of internal charge stabilization by resonance.<smiles>[R][R]([R])P([R])[Z17]([R])([R])CCB([R])[R]</smiles>

\section{1}

The lack of accessible $\mathrm{d}$ orbitals for bonding in boron makes this resonance interaction even more intriguing. Calculations on vinylboronate esters show a high degree of resonance through the carbon - boron

\footnotetext{
" Current address: Pfizer Inc., Eastern Point Road, Groton, CT 06340 † Current address: EG \& G Idaho Inc., P.O. Box 1625, Mailstop 4107, Idaho Falls, ID 83415.

† Current address: Department of Chemistry, Pikeville College, Pikeville, KY 41501.

Address reprint requests to John E. Bartmess, Department of Chemistry, University of Tennessee, Knoxville, TN 37996-1600.
}

bond [1b], predicting the strong electrophilic reactivity of the resulting electron-deficient double bond.

Boron-stabilized carbanions have been used in solution as synthons for $\alpha$-hydroxy carbanions [2-6]. These are generally produced irreversibly; other than the simple bracketing based on how strong an alkyllithium base is necessary to deprotonate these, there are few solution phase $\mathrm{pKa}$ data [7]. Two borinate groups will stabilize a carbanion about as much as three phenyl groups [3]. Only one case is known where a carbanion is stabilized by a single borinate group [8]. Such anions have been observed in the gas phase as well, both from low energy electron impact on triethylborane [9] and by deprotonation of trimethylborane by various anionic bases [10]. In the latter study, a rough bracketing of the acidity of $\left(\mathrm{CH}_{3}\right)_{3} \mathrm{~B}$ proved possible; and the value obtained ( $\Delta \mathrm{G}_{\text {acid }}=360 \pm 5 \mathrm{kcal} / \mathrm{mol}$ ) [11] illustrates that boron-containing functionalities can exhibit greater electron accepting ability than is indicated by their polar substituent parameters. Likewise, alkylborane 2 gives an $(\mathrm{M}-\mathrm{H})^{-}$ion on deprotonation by various bases, with a bracketed acidity of $\Delta \mathrm{G}_{\text {acid }}=$ $362.2 \pm 4.0 \mathrm{kcal} / \mathrm{mol}$ [12].<smiles>C=CB(C)C=CC(C)(C)C</smiles>

The polar effect of a boron group must also be considered. Boron is more electropositive than carbon, but slightly less so than hydrogen. Based on ${ }^{19} \mathrm{~F}$ NMR shifts, a polar substituent constant $\sigma_{1}$ of -0.056 is reported for $-\mathrm{BMe}_{2}$, and -0.07 for $-\mathrm{B}(\mathrm{OMe})_{2}$ [13]. 
The $\sigma_{1}$ substituent parameter for the $-\mathrm{B}(\mathrm{OnBu})_{2}$ group, as derived from the infrared frequencies of the $\mathrm{O}-\mathrm{H}$ stretch in hydrogen bonding from phenol to the borate ester, is comparable to hydrogen with $\sigma=$ 0.0 , and slightly electron accepting relative to methy [14]. The $-\mathrm{B}(\mathrm{nBu})_{2}$ group is between hydrogen and $-\mathrm{B}(\mathrm{OE} t)_{2}$ in its polar effect [14]. The polar effect of these groups is thus small and slightly electron donating; any major stabilizing effect of boron attached to an anion is not due to a polar effect.

If other gas-phase acidities [11] for carbon acids of the $\mathrm{CH}_{3}-\mathrm{G}$ type, where $-\mathrm{G}$ is an electron accepting group such as nitro, cyano, carbonyl, etc., are correlated with the substituent constants $\sigma_{c \%}$ (polarizability), $\sigma_{F}$ (field or inductive effect), and $\sigma_{\mathrm{R}}$ (resonance) [15, 16], eq 1 is obtained.

$$
\Delta G_{\text {acid }}=16.2 \cdot \sigma_{\alpha}-30.6 \cdot \sigma_{\mathrm{F}}-148.3 \cdot \sigma_{\mathrm{R}}+405.0
$$

By using $\sigma_{\mathrm{F}}\left(-\mathrm{BMe}_{2}\right)=-0.056$ from above and $\sigma_{\mathrm{ax}}=-0.4$ (comparable to $-\mathrm{NMe}_{2}$ ), then the abovecited gas-phase acidity for trimethylborane gives $\sigma_{\mathrm{R}}\left(-\mathrm{BMe}_{2}\right)=0.27$, comparable to the largest known for any $-G$, and half again the size of the value for $-\mathrm{NO}_{2}$. It is evident that the $\pi$ electron accepting ability of boron containing substituents can be quite large.

A recent review of the Hammett substituent constants indicates that $-\mathrm{BX}_{2}$ groups have relatively small polar field and resonance interactions $\left(\sigma_{F}\right.$ and $\sigma_{R}<$ 0.1 ) with a benzene ring for $\mathrm{X}=-\mathrm{Me}$ and $-\mathrm{OMe}$, and larger electron accepting effects $\left(\sigma_{\mathrm{F}}\right.$ and $\sigma_{\mathrm{R}} \quad 0.17$ to 0.23 ) for $X=$ halogen [17]. (The parameters $\sigma_{1}$ and $\sigma_{\mathrm{F}}$ are essentially equal numerically.)

There have been several reports [18-20] of borate and borinate ion chemistry in the gas phase. There are several revealing differences between the chemistry that we observe and that reported by others [19], which we believe are due to the different time scales of drift versus trapped cell ion cyclotron resonance (ICR) spectrometry. There have been other studies concerning the ionic Lewis acid chemistry of boranes in the gas phase [21], but little systematic work on the Bronsted chemistry. Borate and boronate derivatives have been used in mass spectrometry [22]. To further examine the ability of boron to stabilize adjacent anions, as well as to examine reactivity related to the Lewis acidity of such species in the gas phase, we have investigated the gas-phase ion chemistry of a number of borate and boronate csters by using pulsed ICR spectrometry.

\section{Experimental}

All experiments were carried out by using an ICR spectrometer which has been previously described [23]. Much of the work in this study was carried out by using a computer controlled system for the ICR spectrometer, operating under either intermediate passage conditions [24] for quantitation of peak intensities, or Fourier transform conditions for mass identification. The ICR cell is a cubic cell utilizing a capacitance bridge detector [24]. The Fourier transform capabilities of this instrumentation involve a partial IonSpec data system, interfaced to an IBM $8088 \mathrm{PC}-1$ computer by means of a Tecmar Labmaster board. We are currently limited to $32 \mathrm{~K}$ transforms due to memory limitations of the $P C$. Iypical conditions for data acquisition include $7 \mathrm{~V}$ p-p chirp excitation from a Rockland frequency synthesizer over the frequency range corresponding to the masses of interest, digitization of the signal at up to $2 \mathrm{MHz}$ as appropriate by the Nyquist criterion, and fast Fourier transform with the MicroWay 87FFT software (Program 87FFT ${ }^{\mathrm{TM}}$, Ver. 1.1.2, MicroWay Inc., Kingston, MA), after one zero fill and Blackman-Harris apodization [25]. Neutral gas pressures were generally in the range of $5 \times 10^{-7}$ to $5 \times$ $10^{-6}$ torr. Spectra are presented in magnitude mode. In general, the instrument is tuned by using rapid scan conditions, for real-time feedback of the effect of changing parameters, then Fourier transform spectra are acquired to survey what reactions are occurring. Finally, rate and equilibrium constants are determined by using rapid scan detection, which is more accurate for signal intensities than Fourier transform detection [26].

Trimethylborate and triethylborate were obtained commercially (Aldrich Chemical Co., Milwaukee, WI) and were distilled under nitrogen prior to use. The alkylboronate esters 4 and 5 were synthesized by the general method of Matteson et al. [5] and were used after distillation of the samples over a $0.5{ }^{\circ} \mathrm{C}$ range (compound 4, b.p. $132.5-133.0^{\circ} \mathrm{C}$; compound 5, b.p. $151.5-152.0^{\circ} \mathrm{C}$ ). Alkoxide anions were generated by dissociative electron attachment to the corresponding nitrite esters, which were prepared in situ [27]. $\mathrm{Hy}$ droxide and amide ions were generated by electron impact on water and ammonia, respectively. All compounds were subjected to the usual freeze-pump-thaw cycles on the ICR forcline immediatcly prior to use. $A 11$ reaction sequences were confirmed by double resonance techniques [28].

\section{Results}

\section{Positive Ion Chemistry}

Borate esters. Conventional mass spectrometric studies of trimethylborate [14] and triethylborate [29] have documented the unimolecular fragmentation patterns of these compounds under electron impact. At moderately low pressures (ca. $5 \times 10^{-7}$ torr) and short reaction times ( $50 \mathrm{msec}$ ), we observe essentially the same ions as seen by Hettich et al. [18]. In the ICR spectrometer, the unquenched spectrum of trimethylborate, corresponding roughly to long reaction times [30], shows only two ion-molecule products. The major product ion is the cluster of masses from $\mathrm{m} / \mathrm{z} 175$ to 177 , 
corresponding to two borons or $(2 \mathrm{M}-31)^{+}$. By double resonance, this is the result of addition of the parent radical cation to the neutral molecule with subsequent stabilizing loss of a methoxy radical. The minor product ion, $(2 \mathrm{M}-45)^{+}$, is $2 \%$ of the size of the $(2 \mathrm{M}-31)^{+}$ peak. It is the result of an analogous process in which the primary fragment ion $(\mathrm{M}-15)^{+}$adds to the neutral borate, followed by loss of a $\mathrm{CH}_{2} \mathrm{O}$ group. All other primary fragment ions disappear by rapid reaction via charge transfer to the neutral borate. This is similar to the pattern of reactivity seen in high pressure chemical ionization mass spectrometry using trimethylborate as a reagent gas [22].

Triethylborate has a primary fragmentation spectrum somewhat more complicated than the methyl ester [18]. Double resonance indicates that the processes giving rise to these peaks are all very similar: each primary fragment ion $\mathrm{A}^{+}$or the parent radical cation adds to the neutral borate, followed by loss of some neutral fragment, usually the ethoxy radical. Again, we observe essentially the same reactivity pattern as Hettich et al. [18].

The reactions of neutral borate esters with a variety of ionic reagents are summarized in Table 1 . Two major reaction pathways are observed: proton transfer, and nucleophilic attack at boron, with accompanying loss of HOR. This latter pathway is effectively a ligand exchange at boron, but with the charge transferred as a proton to the boron compound. Reaction with $\mathrm{CH}_{5}^{+}$ results in proton transfer only, because the conjugate base of the cationic acid is nonnucleophilic. Protonated water, methanol, and ethanol give both simple proton transfer forming $(\mathrm{RO})_{2} \mathrm{~B}-\mathrm{O}^{+}(\mathrm{H}) \mathrm{R}$, and ligand exchange plus proton transfer. Acids weaker than protonated ethanol give only ligand exchange with the proton ending up on the most basic site, usually the new boron species. Even the neutral borate ester can act as a ligand source: $\mathrm{B}(\mathrm{OMe})_{3}$ reacts with $\left[(\mathrm{E}+\mathrm{O})_{2} \mathrm{~B}\right]_{2} \mathrm{OEt}^{+}$with ligand interchange.

It is not trivial to determine the gas-phase basicity of the borate esters, because of this facile ligand interchange. MNDO calculations [31] predict that the gasphase basicity of $\mathrm{B}(\mathrm{OMe})_{3}$ should be comparable to that of methanol, and the basicity of $\mathrm{B}(\mathrm{OEt})_{3}$ should be comparable to that of ethanol. Thus, reaction 2 involving both proton transfer and ligand exchange should be approximately thermoneutral for any $R^{\prime}$ group:

$$
(\mathrm{RO})_{3} \mathrm{~B}+\mathrm{R}^{\prime} \mathrm{OH} H_{2}^{+} \rightleftarrows(\mathrm{RO})_{2} \mathrm{BO}(\mathrm{H}) \mathrm{R}^{\prime+}+\mathrm{ROH}
$$

We observe appreciable amounts of both protonated borate and protonated alcohol for $R=R^{\prime}=M e$ or $E t$ in reaction 2. For $\mathrm{B}(\mathrm{OMe})_{3}$ and methanol, the equilibrium appreciably favors the protonated borate ester, though an exact equilibrium constant could not be obtained. When acetonitrile, comparable in basicity to

Table 1. Reaction products of $\mathrm{B}(\mathrm{OR})_{3}$ with various ions

\begin{tabular}{|c|c|c|c|c|}
\hline & Product ions & & & \\
\hline Neutral & Ion & $M+H^{a}$ & $M-L+I^{b}$ & Other \\
\hline $\mathrm{B}(\mathrm{OMe})_{3}$ & $\mathrm{CH}_{5}^{+}$ & $(\mathrm{MeO})_{2} \mathrm{~B}(\mathrm{OMe}) \mathrm{H}^{+}$ & & \\
\hline $\mathrm{B}(\mathrm{OMe})_{3}$ & $\mathrm{H}_{3} \mathrm{O}^{+}$ & $\left(\mathrm{MeO}_{2} \mathrm{~B}(\mathrm{OMe}) \mathrm{H}^{+}\right.$ & $(\mathrm{MeO})_{3-\mathrm{n}} \mathrm{B}(\mathrm{OH})_{n} \mathrm{H}^{+}$ & \\
\hline $\mathrm{B}(\mathrm{OMe})_{3}$ & $\mathrm{MeOH}_{2}^{+}$ & $\left(\mathrm{MeO}_{2} \mathrm{~B}(\mathrm{OMe}) \mathrm{H}^{+}\right.$ & & \\
\hline $\mathrm{B}(\mathrm{OMe})_{3}$ & $\mathrm{EtOH}_{2}^{+}$ & & $(\mathrm{MeO})_{\mathrm{n}-2} \mathrm{~B}(\mathrm{OEt})_{n} \mathrm{H}^{+}$ & \\
\hline $\mathrm{BlOMe}_{3}$ & $\mathrm{MeCNH}^{+}$ & & $(\mathrm{MeO})_{2} \mathrm{~B}-\mathrm{N} \equiv \mathrm{CMe}^{+}$ & \\
\hline $\mathrm{B}(\mathrm{OMe})_{3}$ & $\mathrm{NH}_{4}^{+}$ & & $\left(\mathrm{MeO}_{2} \mathrm{BNH}_{3}^{+}\right.$ & \\
\hline $\mathrm{B}(\mathrm{OMe})_{3}$ & $\mathrm{nPrNH}_{3}^{+}$ & & $(\mathrm{MeO})_{2} \mathrm{BNH}_{2} \mathrm{nPr}^{+}$ & \\
\hline $\mathrm{B}(\mathrm{OMe})_{3}$ & {$\left[(E t O)_{2} B\right]_{2} O(E t)^{+}$} & & $\mathrm{B}_{2}(\mathrm{OEt})_{\substack{5-n \\
n=1.5}}(\mathrm{OMe})_{n}^{+}$ & \\
\hline $\mathrm{B}(\mathrm{OEt})_{3}$ & $\mathrm{MeOH}_{2}^{+}$ & & $(\mathrm{EtO})_{\mathrm{n}-2} \mathrm{~B}(\mathrm{OMe})_{n} \mathrm{H}^{+}$ & \\
\hline$B(O E t)_{3}$ & $\mathrm{EtOH}_{2}^{+}$ & $(\mathrm{EtO})_{2} \mathrm{~B}(\mathrm{OEt}) \mathrm{H}^{+}$ & & \\
\hline $\mathrm{B}(\mathrm{OEt})_{3}$ & $\left\{(\mathrm{MeO})_{2} \mathrm{~B}\right\}_{2} \mathrm{OMe}^{+}$ & & $\mathrm{B}_{2}(\mathrm{OMe})_{\substack{\mathrm{s}-\mathrm{n} \\
n=1-5}}(\mathrm{OEt})_{\mathrm{n}}$ & \\
\hline $\mathrm{B}(\mathrm{OMe})_{3}$ & $\mathrm{NH}_{2}^{-}$ & & $\left(\mathrm{MeO}_{2}\right)_{2} \mathrm{BNH}^{-}$ & \\
\hline $\mathrm{B}(\mathrm{OMe})_{3}$ & $\mathrm{HO}^{-}$ & & $(\mathrm{MeO})_{2} \mathrm{BO}^{-}$ & $(\mathrm{MeO})_{3} \mathrm{~B}(\mathrm{OH})^{-}[\mathrm{M}+1]$ \\
\hline $\mathrm{B}(\mathrm{OMe})_{3}$ & $\mathrm{MeO}^{-}$ & $(\mathrm{MeO})_{3} \mathrm{BH}^{-}$ & & $(\mathrm{MeO})_{4} \mathrm{~B}^{-}[\mathrm{M}+\mathrm{I}]$ \\
\hline $\mathrm{B}(\mathrm{OMe})_{3}$ & $\mathrm{CH}_{2}=\mathrm{CHO}^{-}$ & & $(\mathrm{MeO})_{2} \mathrm{BCH}=\mathrm{CHO}^{-}$ & \\
\hline $\mathrm{B}(\mathrm{OMe})_{3}$ & $\mathrm{O}^{-}$ & & $\left(\mathrm{MeO}_{2} \mathrm{BO}^{-}\right.$ & $\begin{array}{l}(\mathrm{MeO})_{3} \mathrm{BO}^{-}[\mathrm{M}+\mathrm{I}] \\
(\mathrm{M}-\mathrm{H})^{-} \\
\mathrm{HOCH}_{2} \mathrm{O}^{-} \\
(\mathrm{MeO})_{2} \mathrm{BOB}^{-}(\mathrm{OMe})_{3}{ }^{6}\end{array}$ \\
\hline $\mathrm{B}(\mathrm{OEt})_{3}$ & $\mathrm{MeO}^{-}$ & $(\mathrm{EtO})_{3} \mathrm{BH}^{-}$ & $(\mathrm{MeO})_{4-n} \mathrm{~B}(\mathrm{OEt})_{n}^{-}$ & \\
\hline
\end{tabular}

Neutral plus proton or hydride.

Beutral B(OR $)_{3}+$ ion - ROH.

cTertiary ion from reaction of $\left(\mathrm{MeO}_{2} \mathrm{BO}^{-}\right.$with neutral. 
these alcohols [11], is added to the ICR vacuum system, the ligand exchange reaction 3 :

$$
\begin{aligned}
& \mathrm{MeC} \equiv \mathrm{NH}^{+}+\mathrm{B}(\mathrm{OMe})_{3} \rightarrow \\
& \mathrm{MeC} \equiv \mathrm{N}^{+}-\mathrm{B}(\mathrm{OMe})_{2}+\mathrm{MeOH}
\end{aligned}
$$

is observed. Similarly, reaction of $\mathrm{NH}_{4}^{+}$or $\mathrm{nPrNH}_{3}^{+}$ with $\mathrm{B}(\mathrm{OMe})_{3}$ results in ligand exchange and loss of $\mathrm{MeOH}$. This is intriguing in that endothermic proton transfer (approximately $33 \mathrm{kcal} / \mathrm{mol}$ ) from the propylammonium ion to the borate ester must be the first step in such a mechanism, followed by nucleophilic attack at boron, then loss of methanol. This endothermic proton transfer must be driven by the complexation energy of the ion and neutral; for the proton transfer to occur, part of the Lewis acid/base complexation energy must be present at the end of proton transfer, or the reaction would be too slow to observe. AM1 calculations [32] indicate that the complexation enthalpy of 1-aminopropane to protonated $\mathrm{B}(\mathrm{OMe})_{3}$ is ca. $-54 \mathrm{kcal} / \mathrm{mol}$. Although considerably larger than most ion-molecule complexation energies, this is consistent with the covalent $N-B$ bond formed in this step.

Use of protonated benzene as a cationic acid with a relatively nonnucleophilic conjugate base results in establishment of equilibrium with no ligand exchange, with the borate ester $1.1 \mathrm{kcal} / \mathrm{mol}$ more basic than benzene. This yields a $\Delta \mathrm{G}_{\text {hase }}$ for $\mathrm{B}(\mathrm{OMe})_{3}$ of $\mathbf{1 7 5 . 7}$ $\mathrm{kcal} / \mathrm{mol}$ (proton affinity $=181.9 \mathrm{kcal} / \mathrm{mol}$, derived from a $\Delta S_{\text {base }}$ calculated from only the change in symmetry numbers) relative to benzene (gas-phase basicity $=174.6 \mathrm{kcal} / \mathrm{mol}$ [9]). This is consistent with the above results using methanol as a base/ nucleophile; methanol's gas-phase basicity of $\mathbf{1 7 4 . 1}$ $\mathrm{kcal} / \mathrm{mol}$ is only $1.6 \mathrm{kcal} / \mathrm{mol}$ weaker than that of $(\mathrm{MeO})_{3} \mathrm{~B}$. It also is consistent with the reported proton affinity for $(\mathrm{HO})_{3} \mathrm{~B}$ of $175.6 \mathrm{kcal} / \mathrm{mol}$ [33].

Boronate esters. The reactions of the cyclic boronate esters 3-5 can be summarized as shown in Scheme I: simple addition of the ion $\mathrm{M}^{+}$to the neutral boronate, as well as ions arising from loss of fragments $\left(\mathrm{C}_{3} \mathrm{H}_{5} \mathrm{O}\right.$ and $\mathrm{C}_{6} \mathrm{H}_{12} \mathrm{O}$ for $3, \mathrm{CH}_{2} \mathrm{O}$ and $\mathrm{C}_{5} \mathrm{H}_{10} \mathrm{O}$ for 4 and 5) from the addition product. For 4 and 5 , there are also ions from comparable pathways, from the precursor ion $(M-15)^{+}$from 4 and $(M-29)^{+}$from 5. The observed products arise from pathways comparable to those of the borate esters' reactions with neutrals, but without the complications of ligand exchange. The major difference between the positive ion chemistry of the boronates and the borates is that stable ion-molecule addition products $\mathrm{M} \cdot \mathrm{M}^{+-}$are observed with the boronates, presumably because these compounds, unlike the borates, cannot lose a simple alkoxy radical to stabilize the addition complex. Cleavage of a B-O bond can occur, but the ligand is still attached via its

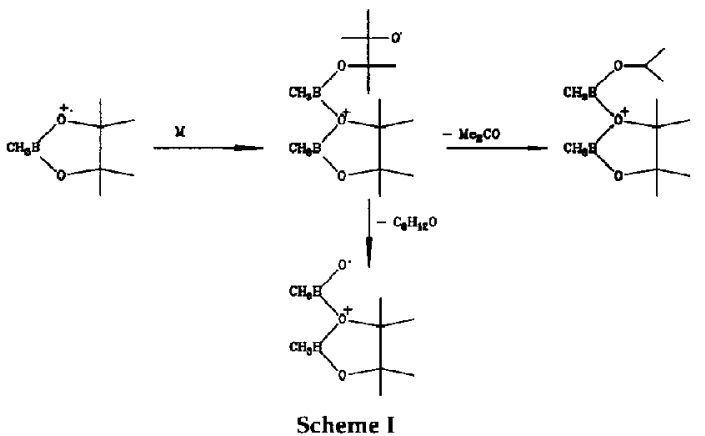

other end to the boron, as shown in Scheme 1 .<smiles>CC1[As]O[As]1OC(C)(C)C(C)(C)C</smiles>

3<smiles>[R]B1OCC(C)CO1</smiles>

4, $\mathrm{R}=\mathrm{Me}$
At the low neutral pressures used in the ICR spectrometer, simple addition of an ion to a neutral species requires some method of disposal of the excess energy of bonding or clustering to stabilize the product with respect to unimolecular dissociation [34]. Such relaxation of the addition complex must be either a collisional or a radiative process [35]. The observed boronate addition complexes exhibit bimolecular rate constants for formation that are not appreciably affected by changes in the neutral pressure, as shown for 5 in Figure 1. At $10^{-6}$ torr, there is an ion-molecule collision on the order of every $30 \mathrm{msec}$. Although we cannot observe emitted radiation directly, it has previously been shown that this lack of pressure dependence may be taken as good evidence for radiative relaxation [35]. For a radiative relaxation process to occur, the complex must have a rate of decomposition comparable to or slower than its rate of radiative

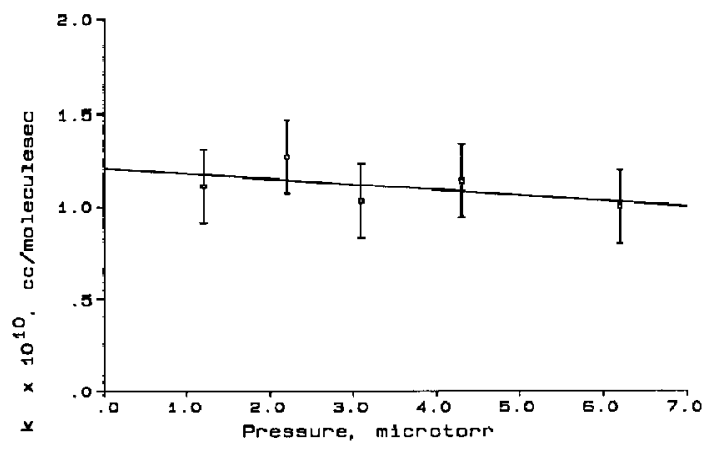

Figure 1. Bimolecular rate constants for formation of $[\mathrm{M} \cdot \mathrm{M}]^{+}$ of 3 , as a function of pressure. 
emission. In the case of the boronate esters, a long complex lifetime is easily rationalized. Assuming that formation of the addition complex is accompanied by cleavage of a $\mathrm{B}-\mathrm{O}$ bond, this creates a large and unconstrained group which adds additional torsions and internal rotations to the complex, greatly increasing the number and density of vibrational states. In addition to this, a complex of this type should have a relatively fast radiative emission rate; theory indicates that compounds having intense infrared absorbance bands in the 1000 to $1300 \mathrm{~cm}^{-1}$ region [35] are likely to have large radiative emission rates. The $\mathrm{B}-\mathrm{O}$ bond has one of the strongest known infrared intensities (large matrix dipole moment) and is in the region of $1350 \mathrm{~cm}^{-1}$. The complexes formed with the boronates 3-5 have three $B-O$ bonds each, and are thus likely candidates for radiative relaxation.

\section{Negative Ion Chemistry}

Borate esters. Trimethylborate and triethylborate react with methoxide to yield both $(\mathrm{M}+\mathrm{H})^{-}$ions and $(\mathrm{M}+31)^{-}$addition products, as given in Table 1 . The former arise from hydride transfer from $\mathrm{CH}_{3} \mathrm{O}^{-}$or $\mathrm{HNO}^{-}$to the boron atom; this has been observed in reactions between methoxide and other Lewis acids $[12,36]$. In regard to the $(M+31)^{-}$ions, as discussed in the preceding section, ionic addition reactions are rare in the pressure regime of the ICR spectrometer, because there is no convenient sink for the excess energy. The attractive forces between the ion and the neutral dipole are great enough that a deep well exists on the potential surface for the complex, so addition complexes are likely to be highly excited species with short lifetimes. MNDO calculations [31] indicate that the methoxide affinity of $\mathrm{B}(\mathrm{OMe})_{3}$ is $39 \mathrm{kcal} / \mathrm{mol}$; at the AM1 level [32], the $\mathrm{B}-\mathrm{O}$ bond in [(MeO)3B $\mathrm{OMe}^{-}$is calculated to be $57 \mathrm{kcal} / \mathrm{mol}$. We have no basis for choosing one of these as being more accurate; however, as noted below, AM1 calculations yield acidities for $\mathrm{R}_{2} \mathrm{BCH}_{3}$ carbon acids $25 \mathrm{kcal} / \mathrm{mol}$ too weak, and acidities for $\mathrm{R}_{2} \mathrm{BOH}$ oxyacids $16 \mathrm{kcal} / \mathrm{mol}$ too strong. We note that MNDO calculations agree to within $5 \mathrm{kcal} / \mathrm{mol}$ with the bond energies for [MeBH2 - $\mathrm{OMe}]^{-}$and $[\mathrm{MeOBH} 2-\mathrm{OMe}]^{-}$calculated at the 4-31G level [19], and also agree with the experimenta] bond energies [37] for $[\mathrm{BH} 3-\mathrm{CN}]^{-}$and $\left[\mathrm{Et}_{3} \mathrm{~B}-\mathrm{H}\right]^{-}$ to within $8 \mathrm{kcal} / \mathrm{mol}$. Also, $\mathrm{MeO}^{-} \cdots \mathrm{HOMe}$ transfers methoxide to $\mathrm{B}(\mathrm{OMe})_{3}[20]$, indicating that experimentally the $\mathrm{B}-\mathrm{O}$ bond strength must be at least 29 $\mathrm{kcal} / \mathrm{mol}$ [38]. We have no reliable experimental upper limit on this bond energy at present. The enolate of methyl acetate has a methoxide affinity of $47 \mathrm{kcal} / \mathrm{mol}$ [11] (i.e., methoxide bound to ketene). It does not transfer methoxide to $\mathrm{B}(\mathrm{OMe})_{3}$, but rather yields an ion corresponding to $(\mathrm{MeO})_{2} \mathrm{BCH}=\mathrm{C}(\mathrm{OMe}) \mathrm{O}^{-}$, equivalent to a Claisen condensation. This cannot be taken as an upper limit to the methoxide affinity of $\mathrm{B}(\mathrm{OMe})_{3}$, therefore. It seems unlikely, however, that this would be as strong as the fluoride bond in $\mathrm{BF}_{4}^{-}$at $71 \mathrm{kcal} / \mathrm{mol}[11]$. We thus say that the methoxide affinity of $\mathrm{B}(\mathrm{OMe})_{3}$ is probably $50 \pm 15 \mathrm{kcal} / \mathrm{mol}$.

Based on these estimates of the energy of bond formation, the initially formed complex must therefore be highly excited vibrationally, and requires some method of disposing of this energy to live long enough to be detected by the ICR technique. The rate constants for appearance of the addition product of methoxide plus trimethyl borate reveal a slight negative pressure dependence: The apparent bimolecular rate constant decreases from $3.0 \times 10^{-10} \mathrm{~cm}^{3} / \mathrm{mol} \cdot \mathrm{sec}$ at $9.0 \times 10^{-8}$ torr, to $1.0 \times 10^{-10} \mathrm{~cm}^{3} / \mathrm{mol} \cdot \mathrm{sec}$ at $5.3 \times 10^{-7}$ torr, with uncertainties in the rate constants of ca. $25 \%$. We are not sure whether the negative pressure dependence is an artifact, possibly due to more complete internal thermalization of the reactant methoxide at the higher pressures, but a similar negative pressure dependence was seen for alkoxide addition to alcohols [35]. Arguments for this process being in part radiative may be made along the same lines as for the positive ion complexes: good infrared radiative structures exist in the four $\mathrm{B}-\mathrm{O}$ bonds in the adduct.

It is noteworthy that in a drift cell ICR experiment [19], similar adducts were noted but were attributed to collisional stabilization at the relatively high pressures used ( $1 \times 10^{-5}$ torr). Adduct formation was found in that case to be considerably more facile for alkoxides adding to borate esters than for the same alkoxides adding to trialkylboranes [19]. This was attributed to the reduced Lewis acidity of $\mathrm{B}(\mathrm{OR})_{3}$ relative to $\mathrm{BR}_{3}$. In light of the present study, the radiative ability of $(\mathrm{RO})_{4} \mathrm{~B}^{-}$with four $\mathrm{B}-\mathrm{O}$ bonds versus that of $R O\left(R^{\prime}\right)_{3} B^{-}$with only one may be a more important factor.

For $\mathrm{B}(\mathrm{OEt})_{3}$ reacting with methoxide, an $(\mathrm{M}+45)^{-}$ ion is observed, which double resonance studies indicate is derived from the $(M+31)^{-}$addition product, and not from an ion of $m / z 45^{-}$. This indicates that an exchange of alkoxide ligands can occur on the collision of the addition product $(\mathrm{EtO})_{3} \mathrm{~B}^{-} \mathrm{OMe}$ with another neutral borate molecule. Similar ligand interchange was observed in the drift cell study [19] for borate esters, but not for trialkylboranes. If methanol is present in the vacuum system, then methoxy and ethoxy ligands are both available for exchanges into the addition products on collision with methanol or with the borate. Figure 2 illustrates the unquenched spectrum [30] obtained in this experiment; it shows a series of peaks with a spacing of 14 mass-to-charge ratios in the range of $m / z 135^{-}$to $m / z 191^{-}$. When no methanol is present, only $(\mathrm{E} t \mathrm{O})_{3} \mathrm{~B}(\mathrm{OMe})^{-}$at $m / z \quad 177^{-}$and $(\mathrm{EtO})_{4} \mathrm{~B}^{-}$at $m / z 191^{-}$are observed. As the methanol pressure is increased, the relative intensity of the higher mass peaks decreases and $(\mathrm{E}+\mathrm{O})_{2} \mathrm{~B}(\mathrm{OMe})_{2}^{-}$at $m / z$ $163^{-}, \mathrm{EtOB}(\mathrm{OMe})_{3}^{-}$at $m / z 149^{-}$, and $(\mathrm{MeO})_{4} \mathrm{~B}^{-}$at $m / z 135^{-}$grow in. The spectrum shown represents approximately equal pressure of methanol and triethyl borate. Scheme II illustrates the sequential exchange 


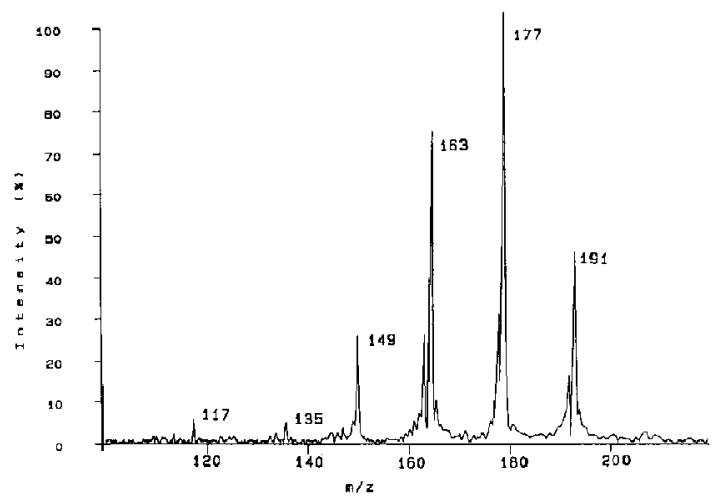

Figure 2. Unquenched mass spectrum of reaction of $(\mathrm{EtO})_{3} \mathrm{~B}$ with methoxide. Scale is in daltons.

equilibria involved in the generation of such a spectrum. Exchanges of the ligands may occur on collision with either the neutral borate or methanol.

One problem dealing with structural assignments involves the ion at $m / z 149^{-}$. Nominally $\mathrm{EtOB}^{-}(\mathrm{OMe})_{3}$ by Scheme II, this might also arise as shown in the elimination/addition reaction 4:

$$
\begin{gathered}
\mathrm{MeO}^{-}+\mathrm{B}(\mathrm{OEt})_{3} \\
\rightarrow\left[\mathrm{MeOH}+\mathrm{CH}_{2}=\mathrm{CH}_{2}+{ }^{-} \mathrm{OB}(\mathrm{OEt})_{2}\right] \\
m / z 117^{2}
\end{gathered}
$$

However, this ion should also undergo the ligand exchange reaction described above with the methanol present, culminating in $\mathrm{HOB}^{-}(\mathrm{OMe})_{3}$ at $121^{-}$. No ion of that mass is observed in the spectrum, implying that this elimination/clustering mechanism is not operating. The presence of a small peak at $m / z 117^{-}$in Figure 2 indicates that some elimination occurs, but without the clustering shown. This peak is not present

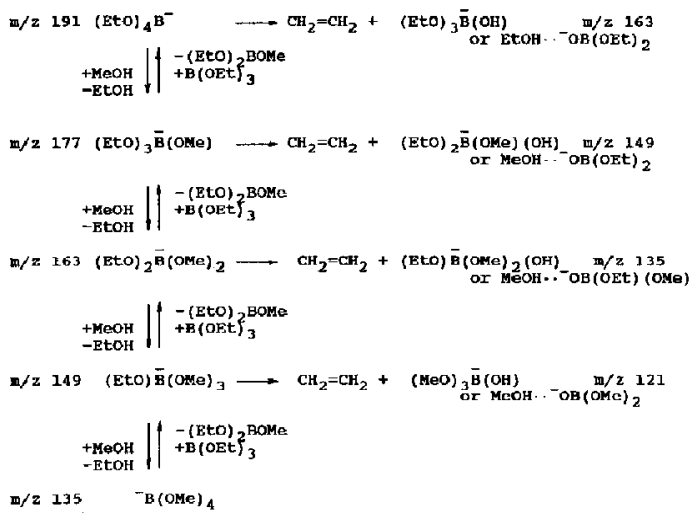

Scheme II in the spectrum at long reaction times, indicating that it is a very minor product, formed slowly. This agrees with the results from drift cell ICR investigations [19] of this system, where small amounts $(1-3 \%)$ of $(\mathrm{RO})_{2} \mathrm{BO}^{-}$product are produced, from either displacement $(\mathrm{R}=\mathrm{Me})$ or elimination $(\mathrm{R}=\mathrm{Et})$ reactions, with a variety of alkoxide reactants. In our trapped cell experiments, when $\mathrm{O}^{-}$is used as the primary ion with $\mathrm{B}(\mathrm{OMe})_{3},(\mathrm{MeO})_{2} \mathrm{BO}^{-}$becomes the most prominent signal in the spectrum, ca. $62 \%$ of the ionic products. This ion reacts with $(\mathrm{MeO})_{3} \mathrm{~B}$ to give an addition product, $(\mathrm{MeO})_{2} \mathrm{BOB}(\mathrm{OMe})_{3}^{-}$. The acidity of the conjugate acid of $(\mathrm{MeO})_{2} \mathrm{BO}^{-}$is bracketed between $\mathrm{tBuCH}=\mathrm{NOH}\left(\Delta G_{\text {acid }}=355.8\right)$ and pyrrole $\left(\Delta \mathrm{G}_{\text {acid }}=350.9\right)[11]$, yielding $\Delta \mathrm{G}_{\text {acid }}=353.4 \pm 4.5$ $\mathrm{kcal} / \mathrm{mol}$ for $(\mathrm{MeO})_{2} \mathrm{BOH}$. By using statistical mechanics to calculate $\Delta \mathrm{S}_{\text {acid }}$ [11], a $\Delta \mathrm{H}_{\text {acid }}$ of $360.3 \pm 4.8$ $\mathrm{kcal} / \mathrm{mol}$ is found, compared to a value from the MNDO method [31] of $361.1 \mathrm{kcal} / \mathrm{mol}$.

The acidities of $\mathrm{XOH}$ compounds of this type have been shown by Taft et al. [15] to be correlated with a master equation:

$$
\Delta G_{\text {acid }}=23.4 \cdot \sigma_{\alpha}-73.4 \cdot \sigma_{\mathrm{F}}-72.8 \cdot \sigma_{\mathrm{R}}+384.5
$$

where $\sigma_{\alpha}, \sigma_{\mathrm{F}}$, and $\sigma_{\mathrm{R}}$ are polarizability, field/inductive, and resonance parameters, respectively. A $\sigma_{\mathrm{F}}$ value of -0.07 for the $-\mathrm{B}(\mathrm{OMe})_{2}$ group is available from ${ }^{19} \mathrm{~F} \mathrm{NMR}$ shift data [13], and the polarizability of $-\mathrm{B}(\mathrm{OMe})_{2}$ is taken as equal to that of the corresponding alkyl group, for $\sigma_{\alpha}=-0.72$ [15]. This latter is justified because the bulk polarizability of $(\mathrm{EtO})_{3} \mathrm{~B}$ is within $2 \%$ of that for $(\mathrm{EtO})_{3} \mathrm{CH}$ and $\mathrm{Et}_{3} \mathrm{CH}$ [39]. By using the $\sigma_{\mathrm{R}}$ for $-\mathrm{BMe}_{2}$ of 0.27 , derived at the beginning of this article, a $\Delta G_{\text {acid }}$ of $353.1 \mathrm{kcal} / \mathrm{mol}$ is calculated from the equation, agreeing very well with the experimental value. This may be fortuitous in that the $-\mathrm{B}(\mathrm{OMe})_{2}$ group would be expected to be not as good in stabilizing negative charge by resonance as $-\mathrm{BMe}_{2}\left(\right.$ smaller $\sigma_{\mathrm{R}}$ ), due to electron donation from the oxygens to the boron reducing its accepting ability. Considering the uncertainties in the values for the field and polarizability parameters, we view this application of eq 5 as semiquantitative, but in agreement with the experimental results.

Reaction of $\mathrm{NH}_{2}^{-}$with $\mathrm{B}(\mathrm{OMe})_{3}$ results in production of $(\mathrm{MeO})_{2} \mathrm{BNH}^{-}$, presumably by an addition/ elimination/deprotonation sequence of reactions. MNDO calculations predict $\Delta \mathrm{H}_{\text {acid }}=374.5 \mathrm{kcal} / \mathrm{mol}$ for the neutral amine; no attempt was made to bracket the acidity directly.

Boronate esters. The initial impetus for this work was to produce and examine the properties of carbanions generated $\alpha$ to boron atoms. MNDO calculations yield an anion proton affinity $\left(\Delta \mathrm{H}_{\text {acid }}\right)$ of $380.0 \mathrm{kcal} / \mathrm{mol}$ for 4. Because MNDO calculations yield a value for the anion proton affinity of trimethylborane of 360.7 $\mathrm{kcal} / \mathrm{mol}$, within $1 \mathrm{kcal} / \mathrm{mol}$ of the experimentally determined gas-phase number [11], we are reasonably confident of their general accuracy in this case. The 
acidity calculated for 4 is comparable to that of methanol $\left(\Delta \mathrm{H}_{\text {acid }}=380.6 \pm 2.3 \mathrm{kcal} / \mathrm{mol}\right)$ [11]. We thus expect that methoxide thermochemically should be able to deprotonate boronate esters in the ICR spectrometer.

Boronate ester 3, used in solution as a source of $\alpha$-boron carbanions [2-4], in the gas phase displays an alternate reactivity on treatment with strong anionic bases, $\mathrm{An}(\mathrm{M}-\mathrm{H})^{-}$ion is observed when 3 is reacted with methoxide. However, this $(\mathrm{M}-\mathrm{H})^{-}$ion does not exhibit the expected two deuterium exchange products when CH3OD is admitted to the system [41], an observation which is consistent with the elimination product shown in reaction 6 . The threshold for this elimination process is at approximately $\Delta \mathrm{G}_{\text {acid }}=370 \pm 5$ $\mathrm{kcal} / \mathrm{mol}$ (bracketed as occurring between methoxide and neopentoxide; $\Delta \boldsymbol{G}_{\text {acid }}$ methanol $=374.0+2$ $\mathrm{kcal} / \mathrm{mol}$, and $\Delta \mathrm{G}_{\text {acid }}$ neopentyl alcohol $=366.2 \pm 2$ $\mathrm{kcal} / \mathrm{mol}$ [11]). A similar elimination product has been proposed elsewhere [19].

$$
\rightarrow \mathrm{MeB}^{\mathrm{MeO}(\mathrm{Me})_{2} \mathrm{C}(\mathrm{Me})=\mathrm{CH}_{2}+\mathrm{MeOH}}
$$

In contrast to 3, boronate ester 4 does not have reaclive sites that could lead to an elimination reaction like 6 [41]. On reaction with methoxide, 4 yields anions at $m / z 127$ and $m / z$ 159. The ion at $m / z 159$ corresponds to the methoxide addition product of 4 . The ion at $m / z 127$ is not the desired $(\mathrm{M}-\mathrm{H})^{-}$ion, however, but rather iodide. The iodide ion is ubiquitous in negative ion mass spectrometry whenever methyl iodide is used in the synthesis of a compound, as was done for 4 and 5 . Evidence for this assignment includes a lack of deuterium exchange into $127^{-}$when MeOD is present, and the complete lack of reactivity of $127^{-}$with any other reagent tried. Boronate ester 5, with the nominal $(\mathrm{M}-\mathrm{H})$ ion shifted to $141 \mathrm{u}$, does not yield an ion at that mass on treatment with methoxide, but instead only an $(M+31)^{-}$ion, plus iodide.

If hydroxide is used as the anionic base, the expected $(\mathrm{M}-\mathrm{H})^{-}$elimination product on reaction with the boronate 3 is observed. There is also a low intensity $(M+1)^{-1}$ ion, attributed to hydroxide addition to boron, followed by methane loss, to give a cyclic $(\mathrm{RO})_{2} \mathrm{BO}^{-}$ion. Addition of hydroxide to 3 is also observed, yielding an $(M+17)^{-}$ion, presumably via an addition/radiative stabilization mechanism, as for the borate esters. When deuteroxide, from $\mathrm{D}_{2} \mathrm{O}$, is used as the base, no deuterium exchange or mass shift is seen for any of these ions, save that the $(M+17)^{-}$ becomes an $(\mathbf{M}+18)^{-}$ion. Similar reactivity is observed for 4 and 5 when deuteroxide generated from $D, O$ is used: replacement of the $R$ group on boron with $-\mathrm{O}^{-}$, but no evidence of a deuterium exchange, as in reaction 7 .

$$
\begin{aligned}
\mathrm{HO}^{-}+\mathrm{RB}\left(\mathrm{OR}^{\prime}\right)_{2} & \rightarrow\left[\begin{array}{r}
\mathrm{HO} \\
\mathrm{R}^{-}-\mathrm{B}^{-} \mathrm{OR}^{\prime}
\end{array}\right] \\
& \rightarrow\left[\mathrm{R}^{-} \cdots \mathrm{HOB}\left(\mathrm{OR}^{\prime}\right)_{2}\right] \\
& \rightarrow \mathrm{RH}+{ }^{-} \mathrm{OB}\left(\mathrm{OR}^{\prime}\right)_{2}
\end{aligned}
$$

Similar addition/elimination mechanisms have been proposed for nucleophilic addition to silicon esters [42]. Based on MNDO heats of formation, the loss of methane by this process is calculated to be essentially thermoneutral from the addition complex, and the addition complex of 4 plus hydroxide is ca. $50 \mathrm{kcal} / \mathrm{mol}$ exothermic from reactants, due to the covalent bond formation. There is thus sufficient energy present in the intermediate to drive this process. The equivalent process is not observed when methoxide is the base; the elimination of two methyl groups as ethane from the complex of borate plus methoxide is calculated to require about $7 \mathrm{kcal} / \mathrm{mol}$ more energy. This is still thermochemically allowed, but may involve a more elaborate mechanism. The $m / z 129^{-}$ion undergoes further reaction, adding to the neutral boronate ester in a (presumably radiative) method, to yield an ( $\mathrm{M}+$ 129) ${ }^{-}$ion. If deuteroxide is used as the primary anion, no deuterium incorporation is observed for $m / z 129^{-}$ or the $(\mathrm{M}+129)^{-}$ions, consistent with the proposed mechanism.

The reaction of $\mathrm{ND}_{2}^{-}$, generated by electron ionization of $\mathrm{ND}_{3}$, with 3,4 , and 5 does not produce any $(\mathrm{M}-\mathrm{H})^{-}$ions, with the exception of the elimination product from 3. Only (1) addition products $(\mathrm{M}+\mathrm{D})^{-}$ and $\left(\mathrm{M}+\mathrm{ND}_{2}\right)^{-}$, (2) addition/fragmentation products such as $(\mathrm{RO})_{2} \mathrm{BND}^{-}$, and (3) hydrogen exchange species from $\mathrm{NH}_{3}$ or $\mathrm{H}_{2} \mathrm{O}$ contaminants into the above ions are observed in the unquenched spectra [30].

\section{Conclusions}

The borate and boronate esters investigated here all undergo Lewis acid/base reactions invalving nucleophilic attack at boron, for both negative and positive ions. All attempts to deprotonate at a $\mathrm{C}-\mathrm{H} \alpha$ to the boron were unsuccessful; only certain reactions involving Lewis attack at the boron first, followed by a proton transfer, resulted in such $\alpha$-boronate anions. This gives $(\mathrm{MeO})_{2} \mathrm{BO}^{-}$and $(\mathrm{MeO})_{2} \mathrm{BNH}^{-}$. Such reactivity is in contrast to the trialkylboranes, where simple proton transfer reactions appear to be facile [19].

The Lewis basicity of the borate and boronate esters dominates their ion-molecule reactivity. Lewis basicity is likewise important for the chemistry of gaseous silicon and titanium esters [20]. For the titanium esters, however, only ligand interchange was observed, and no pentacoordinate titanate anions. For silicon, ligand interchange and pentacoordinate siliconate ions compete fairly evenly. For the borate and boronate esters in this study, the anionic products always involve the boron species; while ligand interchange occurs, the ligands that are lost are neutral alcohols. There thus 
appears to be a range of Lewis basicity for these elements.

\section{Acknowledgments}

We thank the National Science Foundation for support of this work, and Prof. D. S. Matteson for a sample of 3.

\section{References}

1. (a) Progress in Boron Chernistry, Vol. 1-3; Steinberg, $\mathrm{H}$. Melosky, A. L.; Brotherton, R. J., Eds.; Pergamon Press: Oxford, 1964; (b) Matteson, D. S. ibid., Vol. 3, pp 118-134; (c) Brown, H. C., Boranes in Organic Chemistry; Cornell Univ. Press: Ithaca, NY 1972; (d) Borane Reagents; Peltier, A,; Smith, K.; Brown, H. C., Eds.; Academic Press: New York, 1988.

2. Matteson, D. S.; Krämer, E. J. Am. Chem. Soc. 1968, 90, 7261-7266.

3. Matteson, D. S.; Moody, R. J. Organometallics 1982, 1, 20-28.

4. Matteson, D. S.; Sadhu, K. M.; Leinhard, G. E. I. Am. Chem. Soc. 1981, 103, 5241-5242.

5. Matteson, D. S.; Moody, R. J.; Jesthi, P. K. J. Am. Chem. Soc 1975, 97, 5608-5609.

6. Pelter, A.; Bugden, G.; Rosser, R. Tetrahed. Lett. 1985, 26 , 5097-5100

7. Matteson, D. S. Synthesis 1975, 147-158; Rathke, M. W.; Kow, R. J. Am. Chemt. Soc. 1972, 94, 6854-6856; Kow, R.; Rathke, M. W. I. Am. Chem. Sor. 1973, 95, 271.5-2716.

8. Matteson, D. S.; Wilson, J. Organometallics 1985, 4 1690-1694.

9. Johlman, C. L.; Ijames, C. F.; Wilkins, C. L.; Morton, T. H. J. Org. Chem. 1983, 48, 2628-2629.

10. Murphy, M. K.; Beauchamp, J. L. J. Am. Chem. Soc. 1976, 98 , $1433-1440$

11. NIST Negative Ion Energetics Database, SRD Database 19B Bartmess, J. E., Ed. Version 2.1, April 1990. Distributed through Office of Standard Reference Data, National Institute for Standards and Technology, Gaithersburg, Maryland; Lias, S. G.; Bartmess, J. E.; Liebman, I. F.; Holmes, J. L.; Levin R. D.; Mallard, W. G. J. Phys. Chem. Ref. Data, 1988, 17, Suppl.

12. Sullivan, S. A. Ph.D. Thesis, CalTech, 1977. Reported acidities adjusted to new absolute acidity scale in ref 11.

13. Taft, R. W.; Price, E.; Fox, I. R.; Lewis, I. C.; Andersen, K. K.; Davis, G. T. J. Am. Chem. Soc. 1963, 85, 709-724; Taft, R. W. Private communication.

14. Pola, J.; Jakoubková, M.; Chvalovsky, V. Coll. Czech. Chem. Commun. 1979, 44, 3688-3694.

15. Taft, R. W.; Koppel, I. A.; Topsom, R. D.; Anvia, F. I. Am. Chem. Soc. 1990, 112, 2047-2052; Taft, R. W.; Abboud, J. L. M.; Anvia, F.; Berthelot, M.; Fujio, M.; Gal, J.-F.; Headley, A. D.; Henderson, W. G.; J. Am. Chem. Soc. 1988, $110,1797-1800$.

16. Bartmess, J. E; Caldwell, G.; Rozeboom, M. D. I. Am. Chem. Soc. 1983, 105, 340-344.

17. Hansch, C.; Leo, A.; Taft, R. W. Chem. Rev. 1991, 91, 165-195.

18. Hettich, R. L.; Cole, T.; Freiser, B. S. Int. J. Mass Spectrom. Ion Proc, 1987, 81, 203-215.

19. Hayes, R. N.; Sheldon, J. C.; Bowie, J. H. Organometallics 1986, $5,162-167$.

20. van der Wel, H.; Nibbering, N. M. M.; Sheldon, J. C.; Hayes, R. N.; Bowie, J. H. J. Am. Chem. Soc. 1987, 109, 5823-5828.

21. Blair, L. K.; Isolani, P. C.; Riveros, J. M. J. Am. Chem. Soc. 1973, 95, 1057-1060; Haartz, J. C.; McDaniel, D. H. J. Am. Chem. Soc. 1973, 95, 8562-8565; Krivtsov, N. V.; Titova, K. V.; Rosolovskii, V. Ya. Russ. I. Inorg. Chem. 1977, 22, 374-377; Murphy, M. K.; Beauchamp, J. L. Inorg. Chem. 1977, 16
2437-2443; Larson, J. W.; McMahon, T. B. J. Am. Chem. Soc. 1985, 107, 766-773; Larson, J. W.; Szulejko, J. E.; McMahon, T. B. J. Am. Chem. Soc. 1988, 110, 7604-7609; Veljkovic, M.; Neskovic, O.; Zmbov, K. F.; Borshchevsky, A. Y.; Vaisberg, V. E.; Sidorov, L. N. Rapid. Commun. Mass Spectrom. 1991, 5, 37.

22. Dolthun, J. J.; Wiebers, J. L. Org. Mass Spectrom. 1970, 3, 669-681; Suming, H.; Yaozu, C.; Lonfei, J.; Shuma, X. Org. Mass Spectrom. 1985, 20, 719-723; Rothnell, A. P.; Wood, K. V.; Srebnik, M.; Cole, T. E. Org. Mass Spectrom. 1986, 21 , 165-167.

23. McIver, R. T., Jr. Rev. Sci. Instrum. 1970, 41, 555-558; McIver, R. T., Jr. ibid. 1978, 49, 111-118; McIver, R. T., Jr.; Hunter, R. L.; Ledford, E. B., Jr.; Locke, M. J.; Francl, T. J. Int. J. Mass Specfrom. Ion Phys. 1981, 39, 65-84.

24. Hunter, R. L.; Mclver, R. T., Jr. Chem. Phys. Lett. 1977, 49, 577-585; Hunter, R. L.; Mclver, R. T., Jr. Am. Lab, 1977, 9, 13; Hunter, K, L.; Mclver, R. T., Jr. in Lecture Notes in Chemistry, Vol. 31; Hartmann, H.; Wanczek, K.-P., Eds.; Springer-Verlag: Berlin, 1982; pp 464-483.

25. Lee, J. P.; Comisarow, M. B. Appl. Spectros. 1987, 11, 93-98; ibid. 1989, 43, 599-604.

26. Grimm, D. T, Bartmess, J. E. Proceedings of the 39th Annual Conference of the American Society for Mass Spectrometry. Nashville, TN, May 19-24, 1991; p 1521.

27. Caldwell, G.; Bartmess, J. E. Org. Mass Spectrom. 1982, 17 $456-457$.

28. Lehman, T.; Bursey, M. M. Ion Cyclotron Resonance Spectrometry; Wiley: New York, 1976.

29. Wada, Y.; Kiser, R. W. J. Phys. Chem. 1964, 68, 1588-1590; Hammernum, S.; Djerassi, C. Org. Mass Spectrom 1974, 8, 217-227; Fallon, P. J.; Kelly, P.; Lockhart, J. C. Int. J. Mass Spectrom. Ion Phys. 1968, 1, 133-139.

30. Hunter, R. L.; Mclver, R. T., Jr. Anal. Chem. 1979, 51, 699; Bartmess, J. E,; Caldwell, G. Int. J. Mass Spectrom. Ion Phys. 1981, 41, 125-134.

31. Dewar, M. J. S.; Thiel, W. J. Am. Chem. Soc. 1977, 99, 4899 4907; Dewar, M. J. S.; Rzepa, H. S. I. Amt. Chem. Soc. 1978, 100, 784-790; Program No. QCMP005, Quantum Chemistry Program Exchange, Indiana University, Bloomington, Indiana; Dewar, M. I. S.; McKee, M. L. I. Am. Chem. Sac. 1977, 99, 5231-5241.

32. Dewar, M. J. S.; Zoebisch, E. G.; Healy, E. F.; Stewart, J. P. J. J. Am. Chem. Soc. 1985, 107, 3902-3909; Dewar, M. J. S.; Dieter K. M. I. Am. Chem. Soc. 1986, 708, 8075-8086.

33. Attina, M.; Cacace, F.; Ricci, A.; Grandinetti, F.; Occhiucci, G. J. Chem. Soc. Chem. Comm. 1991, 66-68.

34. Bartmess, I. Е. J. Am. Chem. Soc. 1980, 102, 2483-2484.

35. Caldwell, G.; Bartmess, J. E. J. Phys. Chem. 1981, 85 , 3571-3577; Herd, C. R,; Babcock, L. M. I. Phys. Chem. 1987, 91, 2372-2376; Kofel, P.; McMahon, T. B. J. Phys. Chem. 1988, 92, 6174-6176; Herd, C. R.; Babcock, L. M. I. Phys. Chem. 1989, 93, 245-251.

36. Ellis, H. B., Jr.; Ellison, G. B. J. Chem. Phys. 1983, 78, 6541-6558.

37. Workman, D. B.; Squires, R. R. Inorg. Cltem. 1988, 27, $1846-1848$.

38. Meot-ner, M.; Sieck, L. W. I. Phys. Chem. 1986, 90, 6687-6690.

39. Handbook of Chemistry and Physics, 58th ed.; Weast, R. C., Ed.; CRC Press: West Palm Beach, FL, 1977.

40. Stewart, J. $H_{. ;}$Shapiro, R. H.; DePuy, $C_{1} H_{\text {,; }}$ Bierbaum, V. M. J. Am. Chem. Soc. 1977, 99, 7650-7653; DePuy, C. H.; Bierbaum, V. M.; King, G. K.; Shapiro, R. H. J. Am. Chem. Soc. 1978, 100, 2921-2922; Hunt, D. F,; Sethi, S. K. J. Am. Chem. Soc. 1980, 102, 6953-6963; Lloyd, J. R.; Agosta, W. C.; Field, F. H. J. Org. Chern. 1979, 45, 3483-3492.

41. Bartmess, J. E.; Hays, R. L.; Khatri, H. N.; Misra, R. N. Wilson, S. R. J. Am. Chem. Soc. 1981, 103, 4746-4751.

42. Angelini, G.; Johnson, C. E.; Brauman, J. I. Int. J. Mass Spectrom. Ion Proc. 1991, 109, 1-14. 